\section{Quantification of transformation products of unsymmetrical dimethylhydrazine in aqueous extracts from soil based on vacuum-assisted headspace solid-phase microextraction}

Orazbayeva D.*, Kenessov B. Zhakupbekova A

Center of Physical Chemical Methods of Research and Analysis, al-Farabi Kazakh National University, Almaty, Kazakhstan

*E-mail: orazbayeva@cfhma.kz
Quantification of transformation products of unsymmetrical dimethylhydrazine (UDMH) in soil requires tedious, time- and labor-consuming sample preparation. The simple and fast method for quantification of transformation products of UDMH in aqueous extracts from soil using vacuumassisted headspace solid-phase microextraction (Vac-HSSPME) was optimized in this work. The method is based on extraction of analytes from soil with water followed by Vac-HSSPME of the obtained aqueous extracts, and gas chromatography-mass spectrometry analysis. The target transformation products were: pyrazine, 1-methyl-1H-pyrazole, $N$-nitrosodimethylamine, $N, N$ dimethylformamide, 1-methyl-1H-1,2,4-triazole, 1-methyl-imidazole and $1 \mathrm{H}$-pyrazole. The effect of a sample $\mathrm{pH}$ on responses of target analytes was studied. It was negligible, and no $\mathrm{pH}$ adjustment was recommended before a subsequent extraction. The water amount was optimized to provide the best combination of analytes responses and their precision. Extraction by adding $7.00 \mathrm{~mL}$ of water to $2.0 \mathrm{~g}$ of soil ensured linear dependence of responses of the analytes on their concentrations in soil. The optimized method provided detection limits of target analytes in soil in the range from 0.2 to $9 \mathrm{ng} / \mathrm{g}$. The spike recoveries obtained for model samples were in the range $90-103 \%$. The developed method can be recommended for application in laboratories conducting routine analyses of soil samples potentially contaminated by rocket fuel residuals.

Keywords: solid-phase microextraction; vacuum-assisted headspace solid-phase microextraction; transformation products; unsymmetrical dimethylhydrazine; soil analysis.

\section{Определение продуктов трансформации несимметричного диметилгидразина в водных экстрактах из почвы на основе вакуумной парофазной твердофазной микроэкстракции}

Оразбаева Д.С.*, Кенесов Б.Н. Жакупбекова А.A

Центр физико-химических методов исследования и анализа, Казахский национальный университет им. аль-Фараби, Алматы, Казахстан *E-mail: orazbayeva@cfhma.kz
Определение продуктов трансформации несимметричного диметилгидразина (НДМГ) в почве требует сложной, время- и трудозатратной пробоподготовки. В настоящей работе была оптимизирована простая и быстрая методика количественного определения продуктов трансформации НДМГ в водных экстрактах из почвы с использованием вакуумной парофазной твердофазной микроэкстракции (Вак-ПТФМЭ). Методика основана на экстракции аналитов из почвы водой с последующим анализом полученных водных экстрактов при помощи ВакПТФМЭ и газовой хроматографии с масс-спектрометрическим детектированием. Целевыми продуктами трансформации были: пиразин, 1-метил-1H-пиразол, $N$-нитрозодиметиламин, $N, N$-диметилформамид, 1-метил-1H-1,2,4-триазол, 1-метил-имидазол и 1 -пиразол. Исследовано влияние $\mathrm{pH}$ образца на отклики целевых аналитов. Установлено, что влияние $\mathrm{pH}$ незначительно и рекомендовано проводить экстракцию без модификации $\mathrm{pH}$. Оптимизировано количество растворителя (воды) для обеспечения наилучшего сочетания интенсивности и прецизионности откликов аналитов. Экстракция 7,00 мл воды из 2,0 г почвь позволяет получать линейные зависимости откликов аналитов от их концентраций в почве. Оптимизированная методика обеспечивает пределы обнаружения целевых аналитов в почве в диапазоне от 0,2 до 9 нг/г. Степени обнаружения аналитов в модельных образцах методом введено-найдено варьировались в диапазоне 90-103\%. Разработанная методика может быть рекомендована для применения в лабораториях, проводящих рутинный анализ образцов почвы, потенциально загрязненных остатками ракетного топлива.

Ключевые слова: твердофазная микроэкстракция; вакуумная твердофазная микроэкстракция; продукты трансформации; несимметричный диметилгидразин; анализ почвы.

\section{Вакуумды бу фазалы қатты фазалы микроэкстракцияның негізінде топырақтың су сығындыларында симметриялық емес диметилгидразиннін трансформациясы өнімдерін сандық анықтау}

Оразбаева Д.С.*, Кенесов Б.Н. Жакупбекова А.A.

Физика-химиялық зерттеу әдістері орталығы, әл-Фараби атындағы Қазақ ұлттық университеті, Алматы, Қазақстан *E-mail: orazbayeva@cfhma.kz
Симметриялық емес диметилгидразиннің (СЕДМГ) трансформациясы өнімдерін топырақта сандық анықтауы уақыт пен және еңбекті көп қажетсінетін сынама дайындауды қажет етеді. Осы жұмыста вакуумды бу фазалы қатты фазалы микроэкстракцияның (ВакБҚФМЭ) қолдануымен топырақтың су сығындыларында СЕДМГ трансформациясы өнімдерін сандық анықтаудың қарапайым және тез әдістемесі оңтайландырылды. Әдістеме судың қолдануымен сұйық экстракциясы жүргізу, және алынған су сығындыларын Вак-БҚФМЭ мен газды хроматографиясы-масс-спектрометрия арқылы талдауда негізделеді. Мақсатть трансформация өнімдері: пиразин, 1-метил- $1 H$-пиразол, $N$-нитрозодиметиламин, $N, N$ диметилформамид, 1-метил-1H-1,2,4-триазол, 1-метил-имидазол және $1 \mathrm{H}$-пиразол. pH әсерінің шамалы емес екендігі анықталды және рН өзгеріссіз экстракцияны жүргізу ұсынылды. Еріткіштің (судың) мөлшері аналиттердің жауаптарының және олардың дәлдіктерінің үздік комбинациясын қамтамасыз ету үшін оңтайландырылды. 7 мл судың 2 мл топырақтан экстрациясы аналит жауаптарының олардың топырақтағы концентрацияларынан сызықтық тәуелділіктерін алуға мүмкіндік береді. Оңтайландырылған әдістеме топырақта мақсатть аналиттерді 0,2-9 нг/г аралығынд анықтау шектерің көрсетті. Модельдік сынамалардағы енгізілді-табылды әдісі арқылы анықтаудың дәлдіктері 90-103\% аралығында болды. Дайындалған әдістеме зымыран отыны қалдықтарымен ластануы ықтимал топырақ сынамалардың талдауын күнделікті жүргізетін зертханаларда қолдану үшін ұсынылуы мүмкін.

Түйін сөздер: қатты фазалы микроэкстракция; вакуумды қатты фазалы микроэкстракция; трансформациясы өнімдері; симметриялық емес диметилгидразин; топырақты талдау. 


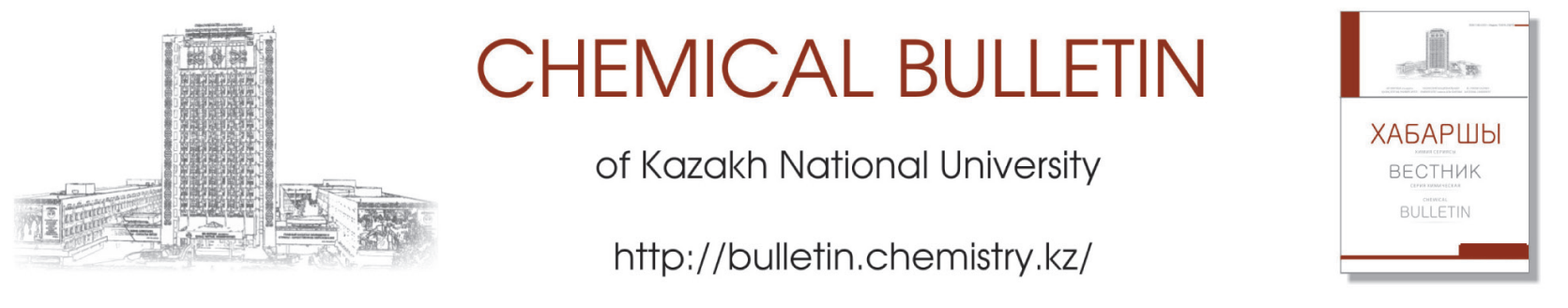

http://doi.org/10.15328/cb1014

\title{
Quantification of transformation products of unsymmetrical dimethylhydrazine in aqueous extracts from soil based on vacuum-assisted headspace solid-phase microextraction
}

\author{
Orazbayeva D.*, Kenessov B., Zhakupbekova A. \\ Center of Physical Chemical Methods of Research and Analysis, \\ al-Farabi Kazakh National University, Almaty, Kazakhstan \\ *E-mail: orazbayeva@cfhma.kz
}

\section{Introduction}

Contamination of environmental objects with highly toxic rocket fuel unsymmetrical dimethylhydrazine (UDMH) is one of the major and the most priority environmental problems in Kazakhstan. Every launch of space vehicles results in environmental pollution due to a landing of rocket parts containing residual fuel $(<2 \mathrm{t})$ on soil and water surfaces. Accidents during transportation or launches of rockets can result in a release of much greater amounts of the fuel [1]. UDMH released into the environment undergoes oxidative decomposition with formation of numerous transformation products (TPs), some of which possess carcinogenic, mutagenic and teratogenic properties [13]. The most stable transformation products of UDMH are triazoles, nitrosoamines, pyrazoles, tetrazoles, imidazoles and pyrazines [4-6].

The majority of methods for quantification of UDMH and its transformation products in soil samples require continuous time- and labor-consuming sample preparation involving organic solvent extraction (Table 1). The headspace solid-phase microextraction (HSSPME) was successfully applied for quantification of UDMH transformation products in soil $[7,8]$. However, the HSSPME methods require complicated calibration approaches to achieve the acceptable accuracy of quantification. Recently, the vacuum-assisted HSSPME (Vac-HSSPME) method was proposed for quantification of transformation products of UDMH in water [9]. Compared to the method based on the regular HSSPME [8], the Vac-HSSPME provided 9-17-fold increase in extraction effectiveness of target analytes at shorter extraction times ( $30 \mathrm{~min}$ vs $60 \mathrm{~min}$ ) and detection limits $0.5-100 \mathrm{ng} / \mathrm{L}$. Matrix effect during Vac-HSSPME can be effectively controlled using multiple extractions from a single sample vial [9]. The similar approach based on Vac-HSSPME cannot be used for soil because it is technically impossible to introduce soil aliquot into an evacuated vial as it is conducted for water. In this study, we propose to conduct the Vac-HSSPME from soil aqueous extracts (Figure 1$)$. Relatively high polarity $\left(\log K_{\text {ow }}\right.$ values in the range from -1.70 to 0.26 ) and water solubility values of target analytes make them suitable for pre-extraction with water followed by HSSPME.

The aim of this work was to optimize the Vac-HSSPME method developed for aqueous samples to soil analysis. The target transformation products were pyrazine (PAn), 1-methyl$1 \mathrm{H}$-pyrazole (MPA), $\mathrm{N}$-nitrosodimethylamine (NDMA), $\quad \mathrm{N}, \mathrm{N}$ dimethylformamide (DMF), 1-methyl-1H-1,2,4-triazole (MTA), 1-methyl-imidazole (MIA), and $1 \mathrm{H}$-pyrazole (PAI). During the optimization step, the effects of water $\mathrm{pH}$ and solvent volume on the intensity and precision of analytes' responses were studied. The analytical performance of the method was determined.

\section{Experimental}

\subsection{Reagents and materials}

The list of reagents (transformation products of UDMH) and their properties are given in the Table 2. The stock and standard solutions were prepared in distilled water.

Mininert ${ }^{\circledast}$ valves (Restek, USA) were modified to fit the $6 \times$ $9 \mathrm{~mm}$ cylindrical Thermogreen ${ }^{\circledR}$ LB-1 septum with half-hole (Supelco, USA) by drilling a 5-mm i.d. hole in it [17].

\subsection{Samples}

Clay and sandy soils collected in Almaty, Kazakhstan were used for preparation of model and standard samples. Before 


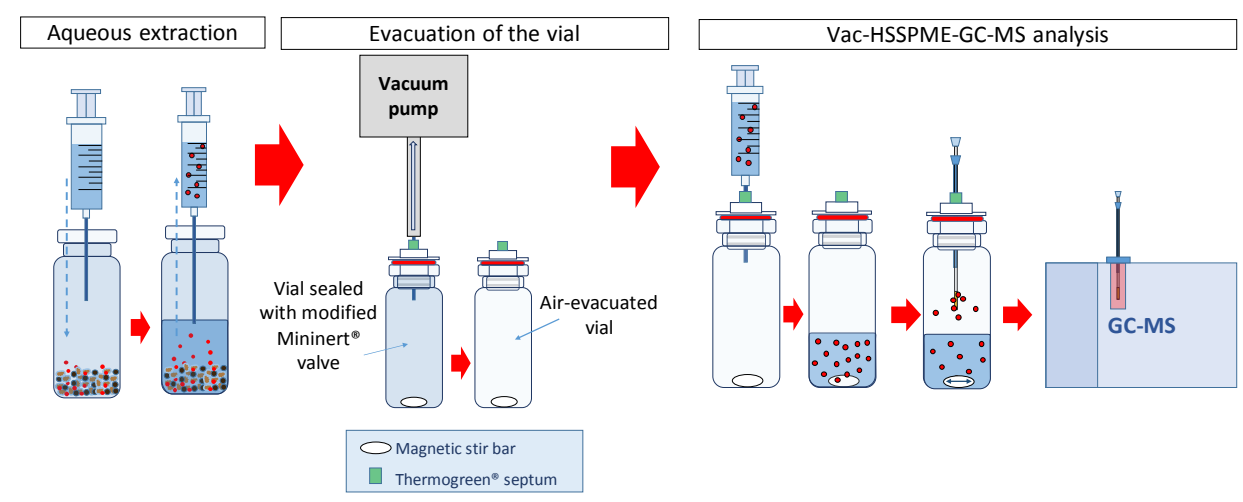

Figure 1 - Proposed scheme for the determination of UDMH TPs in soil using aqueous extraction, Vac-HSSPME and GC-MS

Table 1 - Comparison of the methods used for quantification of UDMH transformation products in soil samples

\begin{tabular}{|c|c|c|c|c|}
\hline Sample preparation method & Analytical instrument & Analyte(s) & Detection limit (ng/g) & Reference \\
\hline Steam distillation from a strongly alkaline & Hydrophilic interaction liquid & UDMH & 2 & [10] \\
\hline medium, trapping into the acetonitrile solution of & chromatography (HILIC), & $\mathrm{MH}$ & 3 & \\
\hline sulphuric acid & HPLC-DAD & Hy & 1 & \\
\hline HSSPME & GC-MS & MTA & $24-1000$ & [7] \\
\hline Continuous periodic extraction with methanol for & HPLC-MS & FDMH & 4 & [11] \\
\hline FDMH; extraction using buffer solutions for MTA & & MTA & 15 & \\
\hline Extraction using acetone or methylene chloride & GC-MS & MTA & 5 & [12] \\
\hline \multirow[t]{2}{*}{ Soxhlet extraction with methanol } & GC-MS & MTA & 20 & [13] \\
\hline & & FDMH & 20 & \\
\hline Distillation from the water-soil slurry in the & HPLC & UDMH & 50 & [14] \\
\hline presence of $\mathrm{NaOH}$ & with amperometric detection & FDMH & 30 & \\
\hline \multirow{3}{*}{$\begin{array}{l}\text { Extraction using } 0.1 \mathrm{M} \mathrm{HCl} \text { during } 24 \mathrm{~h} \text { with } \\
\text { periodic shaking, centrifugation }\end{array}$} & HPLC-MS/MS & MTA & 4 & [15] \\
\hline & & DMF & 4 & \\
\hline & & NDMA & 22 & \\
\hline \multirow[t]{4}{*}{ HSSPME } & GC-MS & 18 analytes including & & [16] \\
\hline & & MTA & 14 & \\
\hline & & DMF & 12 & \\
\hline & & NDMA & 1 & \\
\hline
\end{tabular}

Note: $\mathrm{MH}=$ methylhydrazine; $\mathrm{Hy}=$ hydrazine; $\mathrm{DAD}=$ diode-array detection.

experiments, the soil was washed with water and cleaned from possible analyte residues and water by heating in a drying furnace at $200^{\circ} \mathrm{C}$ for $6 \mathrm{~h}$.

2.3 Parameters of gas chromatography-mass spectrometry (GC-MS) analysis

Analyses were conducted using $7890 \mathrm{~A} / 5975 \mathrm{C}$ system (Agilent, USA) equipped with MPS2 (Gerstel, Germany) autosampler. Desorption of analytes from the SPME fibers into a GC inlet was conducted in a splitless mode for $5 \mathrm{~min}$ at $240^{\circ} \mathrm{C}$. Separation was conducted using a polar $60 \mathrm{~m} \times 0.25 \mathrm{~mm}$ DBWAXetr (Agilent, USA) column with a $0.50 \mu \mathrm{m}$ film thickness at the constant helium ( $>99.995 \%$, Orenburg-Tehgas, Russia) flow $1.0 \mathrm{~mL} / \mathrm{min}$. The temperature program of the oven started from $80^{\circ} \mathrm{C}$ (held for $5 \mathrm{~min}$ ) and heated with the rate $10^{\circ} \mathrm{C} / \mathrm{min}$ 
to $240^{\circ} \mathrm{C}$ (held for $2 \mathrm{~min}$ ). The temperatures of the MS ion source, quadrupole and interface were 230,150 and $240^{\circ} \mathrm{C}$, respectively. Detection was conducted using the electron impact ionization at $70 \mathrm{eV}$ in the selected ion monitoring (SIM) mode. The MS program used for the detection of the UDMH transformation products in the SIM mode is provided in Table 3.

\subsection{Methodology of experiments}

2.4.1 Headspace solid-phase microextraction (HSSPME) procedure

$5.00 \mathrm{~mL}$ of an aqueous sample were introduced into a 20 $\mathrm{mL}$ screw-top headspace vials (HTA, Italy) and spiked with a standard solution of analytes. The sample vials were incubated in the agitator of MPS2 autosampler at $50^{\circ} \mathrm{C}$ and $250 \mathrm{rpm}$ for $10 \mathrm{~min}$. The automated HSSPME was conducted for $30 \mathrm{~min}$ at $50^{\circ} \mathrm{C}$ using Car/PDMS fiber coating.

2.4.2 Study of the effect of $\mathrm{pH}$ of water on responses of analytes

This set of experiments was conducted using aqueous samples prepared from distilled water spiked with PAn and MPA at $100 \mu \mathrm{g} / \mathrm{L}, \mathrm{NDMA}$ and DMF at $200 \mu \mathrm{g} / \mathrm{L}$, and MTA, MIA, PAl at $600 \mu \mathrm{g} / \mathrm{L}$. $5.00 \mathrm{~mL}$ of aqueous samples were introduced into $20-\mathrm{mL}$ screw-top vials and salted-out with $1.75 \mathrm{~g}$ of sodium chloride. Before extraction, $\mathrm{pH}$ of aqueous samples was adjusted to $\mathrm{pH}_{1}=4, \mathrm{pH}_{2}=7$, and $\mathrm{pH}_{3}=10$ using hydrochloric acid or sodium hydroxide solutions, respectively. HSSPME was conducted as described in the Section 2.4.1. The experiment was conducted in three replicates.

\subsubsection{Aqueous extraction procedure}

For Vac-HSSPME analysis, the soil samples were extracted with water. A preset water volume was added to a $20-\mathrm{mL}$ crimp-top vial containing a soil sample aliquot. Vials were sealed with PTFE/silicone septa and aluminum caps, and agitated at $50^{\circ} \mathrm{C}$ and $250 \mathrm{rpm}$ for $15 \mathrm{~min}$. After agitation, the extracts were manually shaken for $2 \mathrm{~min}$ and left to settle for 15 min. The aqueous phase was sampled from unsealed vials using 5-mL gas-tight syringe (Bioject, China) through the $0.22 \mu \mathrm{m}$ polyethersulfone disposable syringe filters (Jin Teng, China).

2.4.4 Study of the effect of water volume on HSSPME responses of analytes from aqueous extracts

Clay soil samples $(\mathrm{m}=5.00 \mathrm{~g}$ ) were weighed in $20-\mathrm{mL}$ crimp-top headspace vials and spiked with PAn at $6.2 \mathrm{ng} / \mathrm{g}$, MPA - at $9.8 \mathrm{ng} / \mathrm{g}$, NDMA and DMF - at $25 \mathrm{ng} / \mathrm{g}$, MTA - at $55 \mathrm{ng} / \mathrm{g}, \mathrm{MIA}$ - at $75 \mathrm{ng} / \mathrm{g}$, and PAl - at $40 \mathrm{ng} / \mathrm{g}$. Different volumes $(8,10,12$, and $15 \mathrm{~mL})$ of distilled water were added to the samples. These solvent volumes were selected in order to provide sufficient liquid phase amount for subsequent VacHSSPME analysis $(5.0 \mathrm{~mL})$. The vials with aqueous extracts were sealed with PTFE/silicone septa and aluminum caps, and agitated at $50^{\circ} \mathrm{C}$ and $250 \mathrm{rpm}$ for $15 \mathrm{~min}$. After agitation, water extracts were manually shaken for $2 \mathrm{~min}$, and left to settle for $15 \mathrm{~min}$. After extraction, $5.0 \mathrm{~mL}$ of liquid phase were sampled into $20-\mathrm{mL}$ screw-top vials using 5 - $\mathrm{mL}$ gas-tight syringe through the syringe filters. The HSSPME from liquid samples was conducted as described in the Section 2.4.1. The experiment was conducted in three replicates.

Table $\mathbf{2}$ - The list of studied compounds and their physicochemical properties

\begin{tabular}{|c|c|c|c|c|c|}
\hline Compound & CAS No. & $\begin{array}{c}\text { Molecular weight } \\
(\mathrm{g} / \mathrm{mol})\end{array}$ & $\begin{array}{c}\mathrm{K}_{\mathrm{H}} \\
\left.\text { (atm } \mathrm{m}^{3} / \mathrm{mol}\right)\end{array}$ & $\log K_{o w}$ & $\begin{array}{c}\text { Boiling point } \\
\left({ }^{\circ} \mathrm{C}\right)\end{array}$ \\
\hline Pyrazine ( $\geq 99.0 \%$, Meryer, China) & $00290-37-9$ & 80.1 & $2.92 \cdot 10^{-6}$ & -0.26 & 115 \\
\hline 1-Methyl-1H-pyrazole ( $\geq 98.0 \%$, Meryer, China) & $00930-36-9$ & 82.1 & $7.88 \cdot 10^{-5}$ & 0.23 & 127 \\
\hline$N$-Nitrosodimethylamine ( $\geq 99.5 \%$, Supelco, USA) & $00062-75-9$ & 74.1 & $1.82 \cdot 10^{-6}$ & -0.57 & 154 \\
\hline$N, N$-Dimethylformamide ( $\geq 99.8 \%$, Lab-Scan, Poland) & $00068-12-2$ & 73.1 & $7.39 \cdot 10^{-8}$ & -1.01 & 153 \\
\hline 1-Methyl-1H-1,2,4-triazole ( $\geq 98.0 \%$, Meryer, China) & $06086-21-1$ & 83.1 & $3.26 \cdot 10^{-5}$ & -0.21 & 187 \\
\hline 1-Methyl-1H-imidazole ( $\geq 99.0 \%$, Meryer, China) & $00616-47-7$ & 82.1 & $8.01 \cdot 10^{-5}$ & -0.06 & 196 \\
\hline $1 \mathrm{H}$-Pyrazole ( $\geq 99.0 \%$, Meryer, China) & 00288-13-1 & 68.1 & $3.69 \cdot 10^{-6}$ & 0.26 & 187 \\
\hline
\end{tabular}

Note: CFC 'Arktika' - Core Facility Center “Arktika” of M.V. Lomonosov Northern (Arctic) Federal University, Arkhangelsk, Russia

Table 3 - MS detection program for the UDMH transformation products in the SIM mode

\begin{tabular}{|c|c|c|c|c|c|}
\hline Analyte & $\begin{array}{l}\text { Retention } \\
\text { time (min) }\end{array}$ & $\begin{array}{c}m / z \text { of quantification ion } \\
\text { (dwell } 100 \mathrm{~ms} \text { ) }\end{array}$ & $\begin{array}{c}m / z \text { of confirmation ion } \\
\text { (dwell } 100 \mathrm{~ms} \text { ) }\end{array}$ & Group & $\begin{array}{l}\text { Start time } \\
\text { (min) }\end{array}$ \\
\hline PAn & 11.74 & 80 & 53 & 1 & 10.0 \\
\hline MPA & 12.44 & 82 & 81 & & \\
\hline NDMA & 13.66 & 74 & 42 & 2 & 13.0 \\
\hline DMF & 14.02 & 73 & 44 & & \\
\hline MTA & 17.58 & 83 & 56 & 3 & 16.0 \\
\hline MIA & 19.13 & 82 & 81 & 4 & 18.6 \\
\hline PAI & 20.23 & 68 & 41 & & \\
\hline
\end{tabular}




\subsubsection{Vac-HSSPME procedure}

$\mathrm{NaCl}(\mathrm{m}=1.75 \mathrm{~g})$ and a $10 \times 6 \mathrm{~mm}$ PTFE-coated magnetic stir bar (Isolab, Germany) were placed into a 20-mL crimp headspace vial and sealed with a modified Mininert ${ }^{\circledR}$ valve. The vial was evacuated for $120 \mathrm{~s}$ using a low-cost rotary vane pump (Russia). Aqueous extract from soil $(\mathrm{V}=5.0 \mathrm{~mL}$ ) was introduced into the air-evacuated vial and placed into the inhouse made heater block for the magnetic stirrer PE-6100 (Ecros, Russia) with temperature control provided by the REX-C100 (Japan) temperature controller and type $\mathrm{K}$ thermocouple 5TC-GG-K-20-36 (Omega, USA) [9]. The samples were extracted for $30 \mathrm{~min}$ after 10 -min incubation at $50^{\circ} \mathrm{C}$ and $1500 \mathrm{rpm}$ stirring speed (maximum stirring rate according to the manufacturer's specifications) using $85-\mu \mathrm{m}$ Car/PDMS fiber.

\subsubsection{Validation of the optimized method}

This set of experiments was conducted on sand samples. For response calibration, five standard samples were prepared by spiking $2.0 \mathrm{~g}$ of sand with standard solutions of target analytes in water for obtaining soil concentrations of PAn $1.9-31 \mathrm{ng} / \mathrm{g}$, MPA 3.1-49 ng/g, NDMA 8.0-128 ng/g, DMF $7.7-123 \mathrm{ng} / \mathrm{g}$, MTA $17-278 \mathrm{ng} / \mathrm{g}$, MIA $13-213 \mathrm{ng} / \mathrm{g}$, PAl 23$375 \mathrm{ng} / \mathrm{g}$. Aqueous extraction was conducted as described in the Section 2.4 .3 by adding $7.0 \mathrm{~mL}$ of distilled water to the soil sample. Calibration slopes and their standard deviations were determined by the least squares method using LINEST function of MS Excel. Recoveries were determined by analyzing two model samples with known concentrations of analytes prepared from sand. All experiments were conducted in three replicates.

\section{Results and Discussion}

\subsection{Effect of $\mathrm{pH}$ of water on responses of analytes}

The target analytes are mostly weak bases, which can be used to facilitate the effectiveness of HSSPME extraction by adjusting the $\mathrm{pH}$ of the samples of water and aqueous extracts from soil. However, any change of $\mathrm{pH}$ of the sample can result in a degradation of UDMH and some of its transformation products with the loss in the method accuracy and precision $[18,19]$.

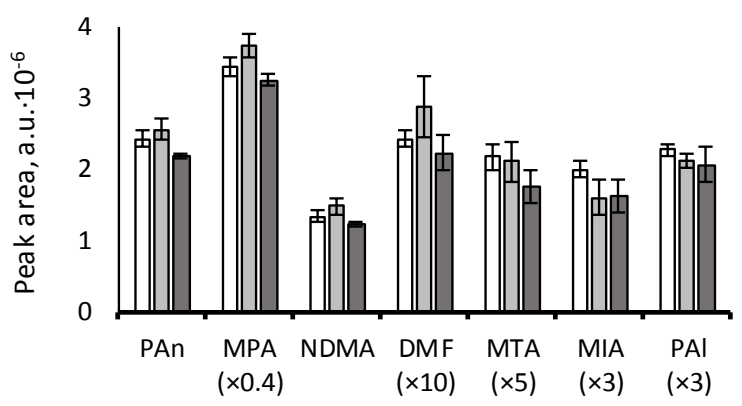

$\square \mathrm{pH} 4 \quad \square \mathrm{pH} 7 \quad \square \mathrm{pH} 10$

Figure 2 - Effect of water $\mathrm{pH}$ on responses of target UDMH transformation products by HSSPME

(extraction temperature $50^{\circ} \mathrm{C}$, extraction time $30 \mathrm{~min}, \mathrm{SPME}$ fiber Car/PDMS, sample volume $5 \mathrm{~mL}$ )
For most target analytes, the effect of $\mathrm{pH}$ on HSSPME responses was negligible (Figure 2). The responses of most target analytes were similar at all $\mathrm{pH}$ values studied in this work $\left(\mathrm{pH}_{1}=4, \mathrm{pH}_{2}=7, \mathrm{pH}_{3}=10\right)$ - the differences were below $25 \%$. Similar insignificant effect of $\mathrm{pH}$ was previously found for HSSPME of nitrosamines [20]. Since the effect of $\mathrm{pH}$ on responses of analytes was found to be negligible, it is optimal to conduct extraction without adjusting $\mathrm{pH}$ of aqueous extracts.

3.2 Effect of extractant volume of responses of analytes from soil aqueous extracts

The decrease of the responses of most target analytes was observed with the increase of solvent amount from 8 to 10,12 and $15 \mathrm{~mL}$ (Figure 3). The decrease of the responses of analytes can be explained by dilution of the aqueous extracts when larger solvent amounts were used. However, when soil comes in contact with water, more complex chemical processes take place, too. The addition of water to soil samples leads to the precipitation of calcium and magnesium bicarbonates even from un-saturated solutions and non-calcareous soils [21] and co-precipitation of other diluted species [22].

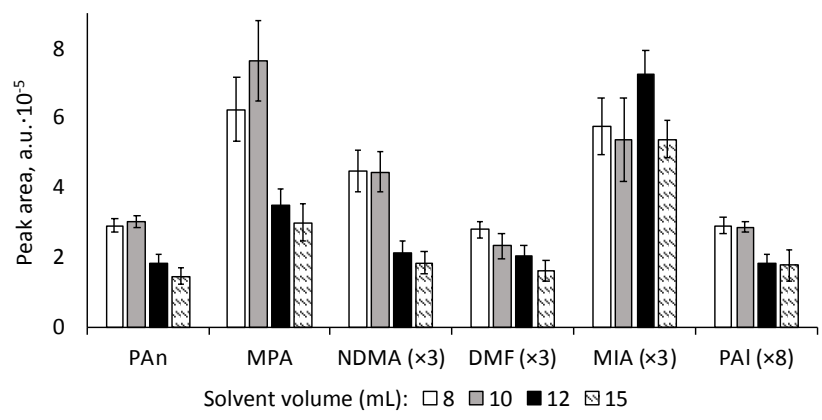

Figure 3 - Effect of solvent (water) volume on Vac-HSSPME responses of analytes from water extracts from soil samples

When using a 5.00-g sample of soil with $10 \mathrm{~mL}$ of water, the increase of responses was virtually not observed at the increase of analytes' concentration, which is required for their quantification. This can be explained by co-precipitation of UDMH TPs at the solid particles available in the mixture after extraction. The effect of co-precipitation can be suppressed by dilution of the soil aqueous solutions with water. For PAn, MPA, and $\mathrm{MIA}$, the increase of responses was observed when increasing the solvent volume up to $12 \mathrm{~mL}$ The more efficient suppression of the co-precipitation, which can be required for other soils, is also possible by using lower mass of soil aliquot and even greater volume of water. In this case, however, detection limits will be increased. Since the sensitivity of the Vac-HSSPME method used in this study allows using lower masses of soil samples, further experiments were conducted on soil samples weighing $2.0 \mathrm{~g}$ and water volume $7.00 \mathrm{~mL}$. This sample-to-solvent ratio provided linear calibration plots for sandy soils with low detection limits of target analytes. However, when analyzing clay or other highly dispersed soil 
samples, the use of larger solvent volumes is required to obtain linear calibration plots.

3.3 Quantification of analytes in soil using Vac-HSSPME

For the studied concentration range, calibration plots with $R^{2}$ values in the range from 0.991 to 0.998 were obtained (Table 4). The RSDs of the slopes of the obtained calibration plots were below $5 \%$ for all target analytes. The method provides good sensitivity with LODs ranging from 0.2 to $9 \mathrm{ng} / \mathrm{g}$. The lowest LOD values were obtained for PAn and MPA, which can be explained by their high extraction effectiveness (9.9 and $27 \%$, respectively [9]) provided by Vac-HSSPME from water samples. The method allows to detect an order of magnitude lower concentrations of NDMA compared to the method based on 24-h continuous extraction using $0.1 \mathrm{M} \mathrm{HCl}$ [15]. For DMF and MTA, comparable detection limits were observed. The detection limits of the proposed method are close to the ones reported for the method of quantification of UDMH TPs using HSSPME from soil and internal standard calibration using deuterated MTA [16]. However, the method based on VacHSSPME does not require internal standard or standard addition calibrations for matrix effect control because of the preliminary solvent extraction of analytes from soil.

The highest slope values of "response - spiked concentration" calibration plots were obtained for PAn and MPA having the highest responses from water samples, too. This could indicate that extraction effectiveness by VacHSSPME from soil aqueous extracts mostly depend on transfer of analytes from liquid sample to the headspace. The recoveries of analytes from spiked sand samples were 90$103 \%$ (Table 5) with RSD of responses in recovery spike samples $0.9-7.7 \%$, which proves the great accuracy of the developed method.

Table 4 - Analytical performance of Vac-HSSPME for aqueous extracts from soil

\begin{tabular}{ccccccc}
\hline Compound & $\begin{array}{c}\text { Studied linear range } \\
\text { (ng/g) }\end{array}$ & $\mathrm{R}^{2}$ & Slope & $\begin{array}{c}\text { RSD of slope } \\
(\%)\end{array}$ & $\begin{array}{c}\text { LOD } \\
(\mathrm{ng} / \mathrm{g})\end{array}$ & $\begin{array}{c}\text { LOQ } \\
(\mathrm{ng} / \mathrm{g})\end{array}$ \\
\hline PAn & $1.9-31$ & 0.997 & 78298 & 2.7 & 0.3 & 1.1 \\
MPA & $3.1-49$ & 0.994 & 196981 & 4.0 & 0.2 & 0.7 \\
NDMA & $8.0-128$ & 0.997 & 8393 & 2.9 & 1.8 & 6 \\
DMF & $7.7-123$ & 0.991 & 7994 & 4.8 & 4 & 13 \\
MTA & $17-278$ & 0.994 & 4695 & 3.7 & 9 & 31 \\
MIA & $13-213$ & 0.998 & 1631 & 2.4 & 4 & 13 \\
PAI & $23-375$ & 0.998 & 6344 & 2.3 & 2 & 6 \\
\hline
\end{tabular}

Note: The LODs and LOQs were calculated as concentrations providing 3:1 and 10:1 signal-to-noise $(S / N)$ ratios, respectively. $S / N$ ratios were measured in calibration standards prepared in sand with lowest concentration of each analyte.

Table 5 - Spike recoveries using the developed method based on Vac-HSSPME (95\% confidence intervals for three replicate measurements)

\begin{tabular}{cccc}
\hline Analyte & $\begin{array}{c}\text { Spiked } \\
(\mathrm{ng} / \mathrm{g})\end{array}$ & $\begin{array}{c}\text { Measured } \\
(\mathrm{ng} / \mathrm{g})\end{array}$ & $\begin{array}{c}\text { Recovery } \\
(\%)\end{array}$ \\
\hline PAn & 15.5 & $14.2 \pm 0.2$ & $91 \pm 2$ \\
MPA & 25 & $24 \pm 3$ & $99 \pm 11$ \\
NDMA & 64 & $57 \pm 5$ & $90 \pm 8$ \\
DMF & 61 & $59 \pm 8$ & $96 \pm 14$ \\
MTA & 139 & $139 \pm 19$ & $100 \pm 13$ \\
MIA & 107 & $109 \pm 11$ & $103 \pm 10$ \\
PAI & 188 & $175 \pm 21$ & $93 \pm 12$ \\
\hline
\end{tabular}

\section{Conclusions}

Thus, the new fast and simple method for the quantification of transformation products of rocket fuel unsymmetrical dimethylhydrazine in soil has been developed using vacuumassisted headspace solid-phase microextraction of aqueous extracts from samples followed by gas chromatography-mass spectrometry analysis. The $\mathrm{pH} 4,7$, and 10 provided similar responses of target UDMH TPs present in water using HSSPMEGC-MS from aqueous solutions. Hence, $\mathrm{pH}$ adjustment of aqueous extracts is not required before extraction. The soil/ water ratio has the great effect on responses of UDMH TPs from 
soil aqueous extracts. To provide better accuracy and precision, the lower soil/water ratios should be used. In this study, $2.0 \mathrm{~g}$ of soil extracted by $7.00 \mathrm{~mL}$ of water provided linear calibration plots with coefficients of determination ranging from 0.991 to 0.998. When using larger soil samples, problems with calibration were observed.

The developed method provides detection limits of target analytes in the range from 0.2 to $9 \mathrm{ng} / \mathrm{g}$. The detection limits were comparable to or lower than those obtained for MTA, DMF, and NDMA using Soxhlet extraction with methanol [13], or extraction using $0.1 \mathrm{M} \mathrm{HCl}$ during $24 \mathrm{~h}$ with periodic shaking and centrifugation [15]. The developed method represents a simpler and faster alternative to the method based on HSSPME [16] because it does not require matrix effect control using internal standard and standard addition calibrations. If matrix effect is observed, it can be controlled using a simpler approach based on multiple Vac-HSSPME [9]. The developed method can be recommended for application in laboratories conducting routine analyses of soil samples potentially contaminated by rocket fuel residuals.

\section{Acknowledgements}

This work was conducted under the project AP05133158 "Development of analytical methods, materials and equipment for cost-efficient "green" environmental monitoring", and Ph.D. project of Dina Orazbayeva both funded by the Ministry of Education and Science of Kazakhstan.

\section{References (GOST)}

1 Carlsen L., Kenesova O.A., Batyrbekova S.E. A preliminary assessment of the potential environmental and human health impact of unsymmetrical dimethylhydrazine as a result of space activities // Chemosphere. - 2007. - Vol.67, Is.6. - P.1108-1116.

2 Carlsen L., Kenessov B.N., Batyrbekova S.Y., Kolumbaeva S.Z., Shalakhmetova T.M. Assessment of the mutagenic effect of 1,1-dimethylhydrazine // Environmental Toxicology and Pharmacology. - 2009. - Vol.28, Is.3. - P.448-452.

3 Carlsen L., Kenessov B.N., Batyrbekova S.Y. A QSAR/QSTR study on the human health impact of the rocket fuel 1,1-dimethylhydrazine and its transformation products // Environmental Toxicology and Pharmacology. - 2009. - Vol.27, Is.3. - P.415-423.

4 Kenessov B.N., Koziel J.A., Grotenhuis T., Carlsen L. Screening of transformation products in soils contaminated with unsymmetrical dimethylhydrazine using headspace SPME and GC-MS // Analytica Chimica Acta. - 2010. - Vol.674, Is.1. - P.32-39.

5 Ul'yanovskii N.V., Kosyakov D.S., Pikovskoi I.I., Khabarov Y.G. Characterisation of oxidation products of 1,1-dimethylhydrazine by high-resolution orbitrap mass spectrometry // Chemosphere. - 2017. - Vol.174. - P.66-75.

6 Kenessov B., Alimzhanova M., Sailaukhanuly Y., Baimatova N., Abilev M., Batyrbekova S., Carlsen L., Tulegenov A., Nauryzbayev M. Transformation products of 1,1-dimethylhydrazine and their distribution in soils of fall places of rocket carriers in Central Kazakhstan // Science of the Total Environment. - 2012. - Vol.427-428. - P. 78-85.

7 Yegemova S., Bakaikina N.V., Kenessov B., Koziel J.A., Nauryzbayev M. Determination of 1-methyl-1H-1,2,4-triazole in soils contaminated by rocket fuel using solid-phase microextraction, isotope dilution and gas chromatography-mass spectrometry // Talanta. - 2015. - Vol.143. - P.226-233.

8 Bakaikina N.V., Kenessov B., Ul'yanovskii N.V., Kosyakov D.S., Pokryshkin S.A., Derbissalin M., Zhubatov Z.K. Quantification of transformation products of unsymmetrical dimethylhydrazine in water using SPME and GC-MS // Chromatographia. -2017. - Vol.80, Is.6. - P.931-940.

9 Orazbayeva D., Kenessov B., Psillakis E., Nassyrova D., Bektassov M. Determination of transformation products of unsymmetrical dimethylhydrazine in water using vacuum-assisted headspace solid-phase microextraction // Journal of Chromatography A. - 2018. - Vol.1555. - P.30-36.

10 Kosyakov D.S., Pikovskoi I.I., Ul'yanovskii N.V., Kozhevnikov A.Y. Direct determination of hydrazine, methylhydrazine, and 1,1-dimethylhydrazine by zwitterionic hydrophilic interaction liquid chromatography with amperometric detection // International Journal of Environmental Analytical Chemistry. - 2017. - Vol.97, Is.4. - P.313-329.

11 Rodin I.A., Anan'eva I.A., Smolenkov A.D., Shpigun O.A. Determination of the products of the oxidative transformation of unsymmetrical dimethylhydrazine in soils by liquid chromatography/mass spectrometry // Journal of Analytical Chemistry. - 2010. Vol. 65, Is. 13. - P.1405-1410.

12 Kenessov B., Batyrbekova S., Nauryzbayev M., Bekbassov T., Alimzhanova M., Carlsen L. GC-MS determination of 1-methyl-1H1,2,4-triazole in soils affected by rocket fuel spills in Central Kazakhstan // Chromatographia. - 2008. - Vol.67, Is.5-6. - P.421-424.

13 Smirnov R.S., Rodin I.A., Smolenkov A.D., Shpigun O.A. Determination of the products of the transformation of unsymmetrical dimethylhydrazine in soils using chromatography/mass spectrometry // Journal of Analytical Chemistry. - 2010. - Vol.65, Is.12. P.1266-1272.

14 Smolenkov A.D., Smirnov R.S., Rodin I.A., Tataurova O.G., Shpigun O.A. Effect of sample preparation conditions on the determination of the total concentrations of unsymmetrical dimethylhydrazine in soils // Journal of Analytical Chemistry. - 2012. Vol.67, Is.1. - P.6-13.

15 Kosyakov D.S., UI'yanovskii N.V., Bogolitsyn K.G., Shpigun O.A. Simultaneous determination of 1,1-dimethylhydrazine and products 
of its oxidative transformations by liquid chromatography-tandem mass spectrometry // International Journal of Environmental Analytical Chemistry. - 2014. - Vol.94. - P.1254-1263.

16 Bakaikina N.V., Kenessov B., Ul'yanovskii N.V., Kosyakov D.S. Quantification of transformation products of rocket fuel unsymmetrical dimethylhydrazine in soils using SPME and GC-MS // Talanta. - 2018. - Vol.184. - P. 332-337.

17 Trujillo-Rodríguez M.J., Pino V., Psillakis E., Anderson J.L., Ayala J.H., Yiantzi E., Afonso A.M. Vacuum-assisted headspace-solid phase microextraction for determining volatile free fatty acids and phenols. Investigations on the effect of pressure on competitive adsorption phenomena in a multicomponent system // Analytica Chimica Acta. - 2017. - Vol.962. - P.41-51.

18 Liang M., Li W., Qi Q., Zeng P., Zhou Y., Zheng Y., Wu M., Ni H. Catalyst for the degradation of 1,1-dimethylhydrazine and its byproduct N-nitrosodimethylamine in propellant wastewater // RSC Advances. - 2016. - Vol.6, Is.7. - P.5677-5687.

19 Mitch W.A., Sedlak D.L. Formation of N-nitrosodimethylamine (NDMA) from dimethylamine during chlorination // Environmental Science \& Technology. - 2002. - Vol.36, Is.4. - P.588-595.

20 Llop A., Borrull F., Pocurull E. Fully automated determination of N-nitrosamines in environmental waters by headspace solidphase microextraction followed by GC-MS-MS // Journal of Separation Science. - 2010. - Vol.33, Is.23-24. - P.3692-3700.

21 Levy R. Precipitation of carbonates in soils in contact with waters undersaturated or oversaturated in respect to calcite // Journal of Soil Science. - 1980. - Vol.31, Is.1. - P.41-51.

22 Hua B., Deng B., Thornton E.C., Yang J., Amonette J.E. Incorporation of chromate into calcium carbonate structure during coprecipitation // Water, Air, and Soil Pollution. - 2007. - Vol.179, Is.1-4. - P.381-390.

\section{References}

1 Carlsen L, Kenesova OA, Batyrbekova SE (2007) Chemosphere 67:1108-1116. http://doi.org/10.1016/j.chemosphere.2006.11.046

2 Carlsen L, Kenessov BN, Batyrbekova SY, Kolumbaeva SZ, Shalakhmetova TM (2009) Environ Toxicol Pharmacol 28:448-452. http://doi.org/10.1016/j.etap.2009.08.004

3 Carlsen L, Kenessov BN, Batyrbekova SY (2009) Environ Toxicol Pharmacol 27:415-423. http://doi.org/10.1016/j.etap.2009.01.005

4 Kenessov BN, Koziel JA, Grotenhuis T, Carlsen L (2010) Anal Chim Acta 674:32-39. http://doi.org/10.1016/j.aca.2010.05.040

5 Ul'yanovskii NV., Kosyakov DS, Pikovskoi II, Khabarov YG (2017) Chemosphere 174:66-75. http://doi.org/10.1016/j. chemosphere.2017.01.118

6 Kenessov B, Alimzhanova M, Sailaukhanuly Y, Baimatova N, Abilev M, Batyrbekova S, Carlsen L, Tulegenov A, Nauryzbayev M (2012) Sci Total Environ 427-428:78-85. http://doi.org/10.1016/j.scitotenv.2012.04.017

7 Yegemova S, Bakaikina NV, Kenessov B, Koziel JA, Nauryzbayev M (2015) Talanta 143:226-233. http://doi.org/10.1016/j. talanta.2015.05.045

8 Bakaikina NV, Kenessov B, Ul'yanovskii NV, Kosyakov DS, Pokryshkin SA, Derbissalin M, Zhubatov Z (2017) Chromatographia 80:931-940. http://doi.org/10.1007/s10337-017-3286-2

9 Orazbayeva D, Kenessov B, Psillakis E, Nassyrova D, Bektassov M (2018) J Chromatogr A 1555:30-36. http://doi.org/10.1016/j. chroma.2018.04.048

10 Kosyakov DS, Pikovskoi II, UI'yanovskii NV, Kozhevnikov AY (2017) Int J Environ Anal Chem 97:313-329. http://doi.org/10.1080/ 03067319.2017.1309036

11 Rodin IA, Anan'eva IA, Smolenkov AD, Shpigun OA (2010) J Anal Chem 65:1405-1410. http://doi.org/10.1134/S1061934810130150

12 Kenessov B, Batyrbekova S, Nauryzbayev M, Bekbassov T, Alimzhanova M, Carlsen L (2008) Chromatographia 67:421-424. http:// doi.org/10.1365/s10337-008-0535-4

13 Smirnov RS, Rodin IA, Smolenkov AD, Shpigun OA (2010) J Anal Chem 65:1266-1272. http://doi.org/10.1134/S1061934810120117

14 Smolenkov AD, Smirnov RS, Rodin IA, Tataurova OG, Shpigun OA (2012) J Anal Chem 67:6-13. http://doi.org/10.1134/ S1061934812010157

15 Kosyakov DS, Ul'yanovskii NV, Bogolitsyn KG, Shpigun OA (2014) Int J Environ Anal Chem 94:1254-1263. http://doi.org/10.1080 /03067319.2014.940342

16 Bakaikina NV, Kenessov B, Ul'yanovskii NV, Kosyakov DS (2018) Talanta 184:332-337. http://doi.org/10.1016/j.talanta.2018.02.047

17 Trujillo-Rodríguez MJ, Pino V, Psillakis E, Anderson JL, Ayala JH, Yiantzi E, Afonso A (2017) Anal Chim Acta 962:41-51. http://doi. org/10.1016/j.aca.2017.01.056

18 Liang M, Li W, Qi Q, Zeng P, Zhou Y, Zheng Y, Wu M, Ni H (2016) RSC Adv 6:5677-5687. http://doi.org/10.1039/C5RA20481J

19 Mitch WA, Sedlak DL (2002) Environ Sci Technol 36:588-595. http://dx.doi.org/10.1021/es010684q

20 Llop A, Borrull F, Pocurull E (2010) J Sep Sci 33:3692-3700. http://doi.org/10.1002/jssc.201000527

21 Levy R (1980) J Soil Sci 31:41-51. http://doi.org/10.1111/j.1365-2389.1980.tb02063.x

22 Hua B, Deng B, Thornton EC, Yang J, Amonette JE (2007) Water Air Soil Pollut 179:381-390. http://doi.org/10.1007/s11270-0069242-7 